\title{
THE EFFECT OF PROTEIN FEED SUPPLEMENTATION TO VARIOUS ROUGHAGE BASAL FEED ON THE PERFORMANCE OF BLIGON GOATS
}

\author{
Kustantinah', H. Hartadi', L.M. Yusiati', R. Utomo', A. Agus', B. Suhartanto', \\ F. Holil ${ }^{2}$ and E. Dahono ${ }^{3}$
}

\begin{abstract}
The research aimed to increase the performance of Bligon goat's kids by feeding protein supplementation Bligon. The research was conducted at the farmer condition, and the animals were divided into two groups consisting of females $(n=24)$ and group of males (15). Feeding treatments consisted of three treatments, first treatment (for females and males) were used as a control, the feedstuffs given were similar to what usually being given by farmer. The second treatment (for females and males) fed a basal feed as farmers usually use for sort of species and quantity, and than supplemented with concentrate containing expired powder milk (CP 18.5\% and TDN $78.0 \%$ ), the third treatment (for female and males) fed a basal feed as farmers usually use and supplemented with concentrate containing leucaena leaf meal (CP 17.8\% and TDN 76.0\%). The observation obtained, DM intake (DMI) for two groups (females and males) did not differ significantly, when the goat received basal feed as roughage and supplemented with expired powder milk, or leucaena leafmeal. In respect of the females group, the DMI varied from $28.2 \mathrm{~g} / \mathrm{kg} \mathrm{LW} /$ day $\left(\mathrm{T}_{1}\right)$ to $31.4 \mathrm{~g} / \mathrm{kg} \mathrm{LW} /$ day $\left(\mathrm{T}_{2}\right)$, these results were slightly higher than the kids that received roughage without supplementation (27.3 $\mathrm{g} / \mathrm{kg} \mathrm{LW} /$ day), while for the male group, the DMI ranged from $31.0 \mathrm{~g} / \mathrm{kg} \mathrm{LW} /$ day $\left(\mathrm{T}_{i}\right)$ to $37.5 \mathrm{~g} / \mathrm{kg} \mathrm{LW} /$ day $\left(\mathrm{T}_{2}\right)$. Body performance of females group and male group in general had a positive correlation, for LW vs. BL, LW vs. HH or LW vs. CC. Even when data obtained were separated between females and males group, for the female group, coefficient of correlation ( $r$ LW vs. CC were, 0.91 ( $n=144$ ), for male group had also a higher value that is $0.89(\mathrm{n}=90)$. The utilization of expired powder milk for weaned females and male goats, give a good ADG, this feedstuffs could be replaced by Leucaena leaf meal. The measurement of body performance, especially Chest circumference (CC) had a good coefficient correlation ( $\mathrm{r}$ ) with live weight (LW).
\end{abstract}

(Key words: Supplementation, Basal feed, Performance, Bligon goats).

Buletin Peternakan $29(4): 163-168,2005$

'Faculty of Animal Science, Gadjah Mada University, Yogyakarta, Indonesia.

${ }^{2}$ International Feed Resources Unit, Macaulay Land Use Research Institute, Aberdeen UK.

${ }^{3}$ Graduated student of Faculty of Animal Science, Gadjah Mada University, Yogyakarta, Indonesia. 


\section{PENGARUH PENAMBAHAN PROTEIN PAKAN PADA BERBAGAI PAKAN BASAL HIJAUAN TERHADAP PERFORMAN KAMBING BLIGON}

\section{INTISARI}

Penelitian ini bertujuan untuk meningkatkan performan anak kambing Bligon dengan pemberian suplementasi protein. Penelitian dilakukan ditingkat petani menggunakan kambing Bligon sebagai materi penelitian, kambing yang digunakan dibagi menjadi dua grup, betina $(n=24)$ dan jantan $(n=15)$. Perlakuan pakan terdiri dari 3 perlakuan, pertama, (untuk betina dan jantan) sebagai kontrol, digunakan pakan yang sama dengan yang biasa diberikan oleh petani. Perlakuan kedua (untuk betina dan jantan) diberi pakan basal sesuai dengan yang biasa diberikan oleh petani dan disuplemetasi dengan konsentrat yang mengandung susu kadaluwarsa (PK 18,5\% dan TDN 78\%), perlakuan ketiga (untuk betina dan jantan) diberi pakan basal sesuai dengan yang diberi petani dan disuplementasi dengan konsentrat yang mengandung tepung daun lamtoro ( $\mathrm{PK} 17,8 \%$ dan $\mathrm{TDN}=76 \%$ ). Observasi yang didapatkan menunjukkan bahwa konsumsi bahan kering (KBK) untuk kedua grup (betina dan jantan) tidak berbeda secara signifikan, apabila ternak kambing diberi makan hijauan dan disuplementasi dengan susu kadaluwarsa atau tepung daun lamtoro. Pada grup anak betina, KBK bervariasi dari $28,2 \mathrm{~g} / \mathrm{kg}$ BB/hari $\left(\mathrm{T}_{1}\right)$ sampai $31,4 \mathrm{~g} / \mathrm{kg} \mathrm{BB} / \mathrm{hari}\left(\mathrm{T}_{2}\right)$, hasil ini sedikit lebih tinggi dibandingkan dengan anak kambing yang diberi hijauan tanpa mendapatkan suplementasi $(27,3 \mathrm{~g} / \mathrm{kg}$ $\mathrm{BB} /$ hari), sedangkan untuk grup anak jantan, $\mathrm{KBK}$ bervariasi dari $31,0 \mathrm{~g} / \mathrm{kg} \mathrm{BB} / \mathrm{hari}\left(\mathrm{T}_{2}\right.$ ) sampai 37,5 $\mathrm{g} / \mathrm{kg} \mathrm{BB} /$ hari. Performan tubuh pada grup anak betina dan grup anak jantan, pada umumnya mempunyai korelasi yang positif untuk Berat Badan (BB) vs. Tinggi Gumba (TG) atau Berat Badan (BB) vs. Lingkar Dada (LD). Pada grup betina, koefisien korelasi ( $\mathrm{r}$ ) BB vs LD adalah 0,91 ( $\mathrm{n}=144$ ) sedangkan untuk grup jantan $0,89(\mathrm{n}=90)$. Penggunaan susu kadaluwarsa untuk anak kambing betina dan jantan lepas sapih memberikan kenaikan berat badan (PBB) yang bagus, bahan pakan ini dapat digantikan dengan tepung daun lamtoro. Pengukuran performan tubuh, menggunakan LD mempunyai keofisien korelasi yang bagus dengan BB.

(Kata kunci: Suplementasi, Pakan Basal, Performan, Anak kambing Bligon).

\section{Introduction}

In Indonesia, goats are one of the favorite small ruminants raised by farmers. Because easier to manage, the reproductive performance is quite high and the price of animal is not too expensive (Kustantinah et al., 2003; C. Fisher, 2002). Farmer able to buy kids than keep them to be fattened or bred. Feed offered usually consist of grasses leaves and also agricultural by products, which vary depend on the harvest time. Usually farmers do not have any problems to fed the animals in the rainy season (November May) because of the basal feed is abundant, but in contrarily, during dry season, generally roughage quality and quantity were very low (Kustantinah et al., 2002; N. Rahmawati, 2004). The waste of powder milk product in milk industry in
Indonesia, was quite abundant, it was around $1000 \mathrm{~kg} /$ month, this product should not be used anymore for human food but still could be used as protein supplementation (CP 28\%) for animal feed, but until now the utilization of expired powder milk is still rarely done.

Considering the problems of low quality of feedstuffs occurring during dry season, the research was meant to introduce the use of protein supplementation for kids weaned at 3 month of age. There were two kinds of protein sources being proposed, the expired powder milk and secondly was leucaena leaf meal.

\section{Material and Method}

In this research which was conducted at naturally farmer condition, Bligon goat kids 
weaning at age between 3 to 5 months were used. The animals were divided into two groups of females $(n=24)$ and of males $(n=15)$. Each group was further divided into three sub groups with 8 kids of females and $5 \mathrm{kids}$ of males.

Treatments consisted of three feeding types, the first type (for females and males) were used as a control, the feedstuffs given were similar as usually given by farmer. The second treatment (for females and males) fed a basal feed as farmers usually use sort of species and quantity, and than supplemented with expired powder milk (CP: $18.5 \%$ and TDN $78.0 \%$ ), the third treatment (for female and males) fed a basal feed as farmers usually use and supplemented with leucaena leaf meal (CP. $17.8 \%$ and TDN $76.0 \%)$.

Supplementation was given for 10 weeks, which started by an adaptation period for two weeks. Roughage basal feed fed two times a day, morning (7.00 pm) and evening (16.00 am). Data being measured were: the sort of feeds and species given by farmers, chemical composition (proximate analysis), feed intake and kids performance (average daily gain, hump height, body length and chest circumference) that measured every two weeks.

\section{Result and Discussion}

From the observation, it was found out that in general farmers in the village fed their goats with roughages without concentrate, and the forage species being used consisted of 15 to 20 species (Table 1). It was shown that the species of roughages being given by farmers for their animals were varies. These research was conducted in the end of dry season (August to October), in this season farmers had never used a single feedstuffs, they always mixed 3 to 5 species of leaves.

The roughages being used could be divided into four groups which were: leguminous (sesbania sesban, leucaena and kancu leaf); grass (king grass and native grasses); leaves (jack fruit, banana and mahogany) and agricultural waste products (corn stover, dry cassava tuber skin). In the period during data collection the utilization of agricultural by products were few due to beyond harvest time.

The crude fiber (CF) content of the feedstuffs that given by farmers were vary ranging between $3.5 \%$ (dry cassava tuber) to $41.4 \%$ (Kancu leaf), while the protein content ranging between $2.0 \%$ (dry cassava tuber) to $27.0 \%$ (Sesbania sesban) (Table 1$)$.

Table 1. Sort and chemical composition of feedstuffs fed by farmers to their goats

\begin{tabular}{lcccccc}
\hline & OM & CP & EE & CF & ETN & TDN* \\
\hline Leguminous: & & & & & & \\
$\quad$ Sesbania sesban leaf (\%) & 89.9 & 27.0 & 4.7 & 16.6 & 42.0 & 74.0 \\
$\quad$ Leucaena leucocephala leaf (\%) & 91.6 & 26.0 & 4.1 & 20.9 & 40.5 & 71.0 \\
$\quad$ Kancu leaf(\%) & 92.2 & 18.0 & 0.4 & 41.4 & 20.3 & 53.3 \\
Grass : & & & & & & \\
King grass (\%) & 89.7 & 12.0 & 3.8 & 31.4 & 42.5 & 59.1 \\
$\quad$ Native grass (\%) & 90.3 & 6.7 & 1.8 & 34.2 & 47.6 & 55.8 \\
Others: & & & & & & \\
Jackfruit leaf(\%) & 75.0 & 13.0 & 4.4 & 20.0 & 38.1 & 56.0 \\
Banana leaf (\%) & 88.1 & 14.0 & 3.8 & 23.1 & 46.9 & 64.0 \\
Mahogany leaf(\%) & 92.45 & 14.0 & 0.7 & 28.2 & 38.2 & 56.4 \\
Agricultural waste product: & & & & & & \\
Dry cassava tuber skin (\%) & 82.3 & 11.0 & 4.3 & 6.5 & 60.3 & 68.0 \\
$\quad$ Corn Stover (\%) & 89.8 & 8.8 & 1.9 & 29.5 & 49.5 & 59 \\
Rice brand (\%) & 88.3 & 14.0 & 14.1 & 11.6 & 48.7 & 74 \\
Dry cassava (\%) & 98.6 & 2.0 & 1.0 & 3.6 & 78.4 & 82.7 \\
\hline
\end{tabular}




\section{Body performance}

The body performance is measured for live weight (LW), humpback height $(\mathrm{HH})$, body length $(\mathrm{BL})$ and chest circumference $(\mathrm{CC})$.

This research was also aimed to study the correlation between variables on body performance, especially live weight and chest circumference, humpback height and body length. The objective is to find the highest coefficient correlation ( $r$ ) between variables. Those equation expected could be used by farmer or anybody who need to measure live weight (LW) by measuring Chest circumference (CC), Body Length (BL) and Humpback Height (HH), which is easier and cheaper compare to weighing animal that required a scale.
Observation of body performance of females group and male group in general had a positive correlation, for LW vs. BL, LW vs. HH or LW vs. CC. When the data were separated for females and males group, as the measurements were done once in two weeks, so the numbers of data were 144 for females group and 90 for male group without considering the feeding treatment. For the female group, coefficient of correlation (r) were higher on LW vs. CC ( $=0.91, n=144)$ (Table 5), also for male group has a higher value that was $0.89(n=90)$ (Table 4). Based on the calculation done, the measurement values of $\mathrm{CC}$ were closely correlated with LW, this measurement were quite accurate and could be accepted for predicting the LW of goat kids for females and males.

Table 4. The regression equation of Live Weight $(Y)$ vs. Chest circumference $\left(X_{1}\right)$, Body Length $\left(\mathrm{X}_{2}\right)$ and Humpback Height $\left(\mathrm{X}_{3}\right)$ of male goat kids

\begin{tabular}{lcccc}
\hline \multicolumn{1}{c}{ Variable } & Regression equation & $\mathrm{R}$ & $\mathrm{R}^{2}$ & $\mathrm{n}$ \\
\hline Chest circumference $\left(\mathrm{X}_{1}\right)$ & $\mathrm{Y}=14.7+0.5 \mathrm{X}_{1}$ & 0.89 & 0.79 & 90 \\
Body Length $\left(\mathrm{X}_{2}\right)$ & $\mathrm{Y}=-6.4+0.4 \mathrm{X}_{2}$ & 0.88 & 0.78 & 90 \\
Humpback Height $\left(\mathrm{X}_{3}\right)$ & $\mathrm{Y}=-23.2+0.7 \mathrm{X}_{3}$ & 0.78 & 0.64 & 90 \\
\hline
\end{tabular}

Table 5. The regression equation of Live Weight $(\mathrm{Y})$ vs. Round Chest $\left(\mathrm{X}_{1}\right)$, Body Length $\left(\mathrm{X}_{2}\right)$ and Gumba height $\left(\mathrm{X}_{3}\right)$ of female goat kids

\begin{tabular}{lcccc}
\hline \multicolumn{1}{c}{ Variable } & Regression equation & $\mathrm{R}$ & $\mathrm{R}^{2}$ & $\mathrm{n}$ \\
\hline Chest circumference $\left(\mathrm{X}_{1}\right)$ & $\mathrm{Y}=-16.2+0.5 \mathrm{X}_{1}$ & 0.91 & 0.82 & 144 \\
Body Length $\left(\mathrm{X}_{2}\right)$ & $\mathrm{Y}=-6.4+0.4 \mathrm{X}_{2}$ & 0.79 & 0.62 & 144 \\
Humpback Height $\left(\mathrm{X}_{3}\right)$ & $\mathrm{Y}=-23.2+0.7 \mathrm{X}_{3}$ & 0.86 & 0.74 & 144 \\
\hline
\end{tabular}

Table 6. The equation regression of LW $(\mathrm{Y})$ vs. Round Chest $\left(\mathrm{X}_{1}\right)$, Body Length $\left(\mathrm{X}_{2}\right)$, and Gumba height $\left(\mathrm{X}_{3}\right)$ for both animals (female and male)

\begin{tabular}{ccccc}
\hline Variable & Regression equation & $\mathrm{R}$ & $\mathrm{R}^{2}$ & $\mathrm{n}$ \\
\hline Chest circumference $\left(\mathrm{X}_{1}\right)$ & $\mathrm{Y}=-16.4+0.5 \mathrm{X}_{1}$ & 0.90 & 0.81 & 246 \\
Body Length $\left(\mathrm{X}_{2}\right)$ & $\mathrm{Y}=-11.8+0.6 \mathrm{X}_{2}$ & 0.79 & 0.62 & 246 \\
Humpback Height $\left(\mathrm{X}_{3}\right)$ & $\mathrm{Y}=-19.9+0.7 \mathrm{X}_{3}$ & 0.84 & 0.71 & 246 \\
\hline
\end{tabular}

Table 7. The equation regression of $L W$ vs. combination with 2 variables which is $C C\left(X_{1}\right)$, and $\mathrm{HH}\left(\mathrm{X}_{3}\right)$ and LW vs. combination with 2 variables which is $\mathrm{CC}\left(\mathrm{X}_{1}\right)$ and $\mathrm{BL}\left(\mathrm{X}_{3}\right)$

\begin{tabular}{ccccc}
\hline Variable & Regression equation & $\mathrm{R}$ & $\mathrm{R}^{2}$ & $\mathrm{n}$ \\
\hline $\begin{array}{c}\text { Chest circumference }\left(\mathrm{X}_{1}\right) \text { and } \\
\text { Humpback Height }\left(\mathrm{X}_{2}\right)\end{array}$ & $\mathrm{Y}=-21.1+0.4 \mathrm{X}_{1}+0.28 \mathrm{X}_{2}$ & 0.93 & 0.86 & 246 \\
$\begin{array}{c}\text { Chest circumference }\left(\mathrm{X}_{1}\right) \text { and } \\
\text { Body Length }\left(\mathrm{X}_{2}\right)\end{array}$ & $\mathrm{Y}=-17.9+0.4 \mathrm{X}_{1}+0.2 \mathrm{X}_{3}$ & 0.91 & 0.83 & 246 \\
\hline
\end{tabular}


When all of the observations without differentiating female and male, the total number of measurements became 246 for LW, CC, $\mathrm{HH}$ and BL, then when the coefficient correlation ( $\mathrm{r}$ ) were calculated, it was found that the coefficient correlation between LW vs. CC also had the highest value compared to $\mathrm{LW}$ vs. BL or LW vs. $\mathrm{HH}$, that were $0.90 ; 0.79$ and $0.84 \quad(\mathrm{n}=246)$ consecutively (Table 6). Then combination of regression calculation was made between $L W$ vs. $\mathrm{CC}$ and $\mathrm{HH}$ or $\mathrm{LW}$ vs. $\mathrm{CC}$ and $\mathrm{BL}$, they were correlated significantly $(\mathrm{P}<0.01)$ (Table 7 ), and had a quite high coefficient correlation ( $r$ ) which were 0.93 and 0.91 , consecutively. The measurements of body performance were very useful estimation of LW, especially of $\mathrm{CC}$, but also should consider the $\mathrm{HH}$ and $\mathrm{BL}$ for the accuracy of measurement of LW, without differentiating the kind of sex of the animals.

\section{Conclusion}

Utilization of expired powder milk as waste product of milk industry for weaned females and male goats, had produced a good ADG, and this feedstuffs could replaced by Leucaena leaf meal.

The measurement of body performance, especially Chest circumference had a good coefficient correlation with live weight. In other words, to measure the live weight could use the data of Chest circumference for both female and male animals.

\section{Acknowledgement}

The authors acknowledge the DFIDBritish Council Indonesia for financial input under higher education Link scheme between Department of Animal Nutrition and Feed Science Faculty of Animal Science, Gadjah Mada University and International Feed resources Unit, Macaulay Land Use Research
Institute, Aberdeen UK and Department of Agriculiure and Forestry, University of Aberdeen UK.

\section{Reference}

Fisher, Corrine, 2002. A Women's group goatsharing scheme in Java, Indonesia. Msc Thesis Department of Agriculture and Forestry, University of Aberdeen, UK.

Insung ${ }^{1} \mathrm{O}$., T. Vearasilp ${ }^{2}, \mathrm{U}$. ter Meulen ${ }^{3}$ and $\mathrm{S}$. Chakeredza ${ }^{3}$. Influences of Plants Species and Conservation Methods on Voluntary Intake and Digestibility of Dry Matter and Organic Matter of Ruzzi grass (Brachiaria ruziziensis) and Streblus Leaves (Streblus asper Lour) in Goats under the Humid Tropical Climate in Southern Part of $\mathrm{T} h$ a $\mathrm{i} \quad \mathrm{l}$ a $\mathrm{n}$ d. http://www.tropentag.de/2004/abstract/ful 1/145.pdf.

Kustantinah, M. A.Lomax, B. Suhartanto, A. Agus, E. R. Orskov, H. Hartadi, R. Utomo and L. M. Yusiati. 2002. A Livestock development Approach contributes to poverty Alleviation: A special case at Kwarasan, Nglipar, Gunungkidul as an example. Proceedings of the $3 \mathrm{rd}$ International seminar on Tropical Animal Production, Faculty of Animal Science, Gadjah Mada University, Yogyakarta, Indonesia.

Kustantinah, M. A. Lomax, B. Suhartanto, Soemitro P. W., H. Hartadi, S. Zubaidah. 2003. Effects drying Process of Cassava Leaves on Its degradability, Proceeding AAAP, UPM, Malaysia.

Rahmawati. N. 2004. The influence of feeding Frequency and concentrate supplementation on Energy intake of Bligon goat. M.Sc. Thesis. Fakultas Pascasarjana, Gadjah Mada University, Yogyakarta, Indonesia. 